\title{
Analysis of the Effect of Heating Temperature on Tension Strength, Elongation and Function Clusters on Composite Tube Aerial Fiber Optic Cable G.652D- STEL-K-036-2012
}

\author{
Herman Perez Purba ${ }^{1}$, Budiarto $^{2}$, and Melya D Sebayang ${ }^{3}$ \\ ${ }^{1,2,3}$ Department of Mechanical Engineering, Universitas Kristen Indonesia, Indonesia
}

\begin{abstract}
The composite material of the fiber optic cable tube (G.652D-Stel-K-036-2012) or Polybutylene Terephthalate (PBT)-Master Batch MB) has been tested for tensile strength, elongation, and functional groups for fiber optic tube cladding materials. The purpose of this study was to determine the effect of heating temperatures of $2500 \mathrm{C}, 2550 \mathrm{C}$, and $2600 \mathrm{C}$ on tensile strength, elongation, and functional groups in PBT-MB composite tube for fiber optic tube cladding material. The PBT-MB composite material was made by mixing PBT ( $80 \%$ by weight) with MB (20\% by weight) in a ball mill. Then put together and processed into a tube on the extruder. Tensile and elongation strength was tested by tensile test, functional group test with FTIR, and humidity test. The results of the tensile test and elongation test increased with increasing heating temperature and still met the specified standard. The results of the functional group test showed that there was a $\mathrm{CH}$ bond from the PBT Tube at the highest wave peak, namely $2923.54 \mathrm{~cm}^{-1} 1,725.10 \mathrm{~cm}^{-1}$, there was also a CH Aldehydes bond at a wavelength of $2852.19 \mathrm{~cm}-1,935.30 \mathrm{~cm}-1,916.02$ $\mathrm{cm}^{-1}, 873.59 \mathrm{~cm}^{-1}, 811.88 \mathrm{~cm}^{-1}$, the carbonyl bond $\mathrm{C}=\mathrm{C}$ at a wavelength of $1708.61 \mathrm{~cm}^{-1}$, and the last is an Aromatic bond at a wavelength of $1504.20 \mathrm{~cm}^{-1}$. The chemical bonds in the test compounds were PBT-MB tube composites. From all the tests carried out, it was concluded that the variation of temperature on the manufacture of PBT-MB tube composites was very influential on the quality and still met the established standards.
\end{abstract}

Keyword: Composite tube PBT-MB, tensile strength, elongation, functional groups.

Received 24 August 2021 | Revised [27 August 2021] | Accepted [27 August 2021]

\section{Introduction}

One of the more advanced efforts to undergo an industrial competition in today's global market is to give a very full attention to increasing the advantages of the products to be produced, in order to meet the quality management standards set by the international. The company will be successful if it can reach the market if can increase the advantages of the goods produced, but

\footnotetext{
*Corresponding author at: Jl. Mayjen Sutoyo No.2, Cawang, Kec. Kramat jati, Kota Jakarta Timur, Daerah Khusus Ibukota Jakarta 13630 
there are criteria that must be considered, namely: determine selling prices that can compete in the global market and provide services to consumers [1].

Currently PT. XYZ is still supplying the cable needs of PT. Telekomunikasi Indonesia Tbk, PT. PLN, PT. Indosat, PT. Telkom Access, PT. Ericson Indonesia, PT. Pertamina, PT. Bukit Asam Tbk, PT. Freeport Indonesia, Hyundai Engineering, Samsung Engineering, PT PAL Indonesia etc. PT. XYZ has implemented ISO 9001 - 2015, ISO 14001 - 2015, and OHSAS 18001 2007. The products produced refer to national and international standards, such as; Indonesian National Standard (SNI), State Electricity Company Standard (SPLN), Telkom Standard (STEL-K-QA), Japanese Industrial Standard (JIS), Deutsch [2]-[4].

\section{Methods}

\subsection{Flowchart}

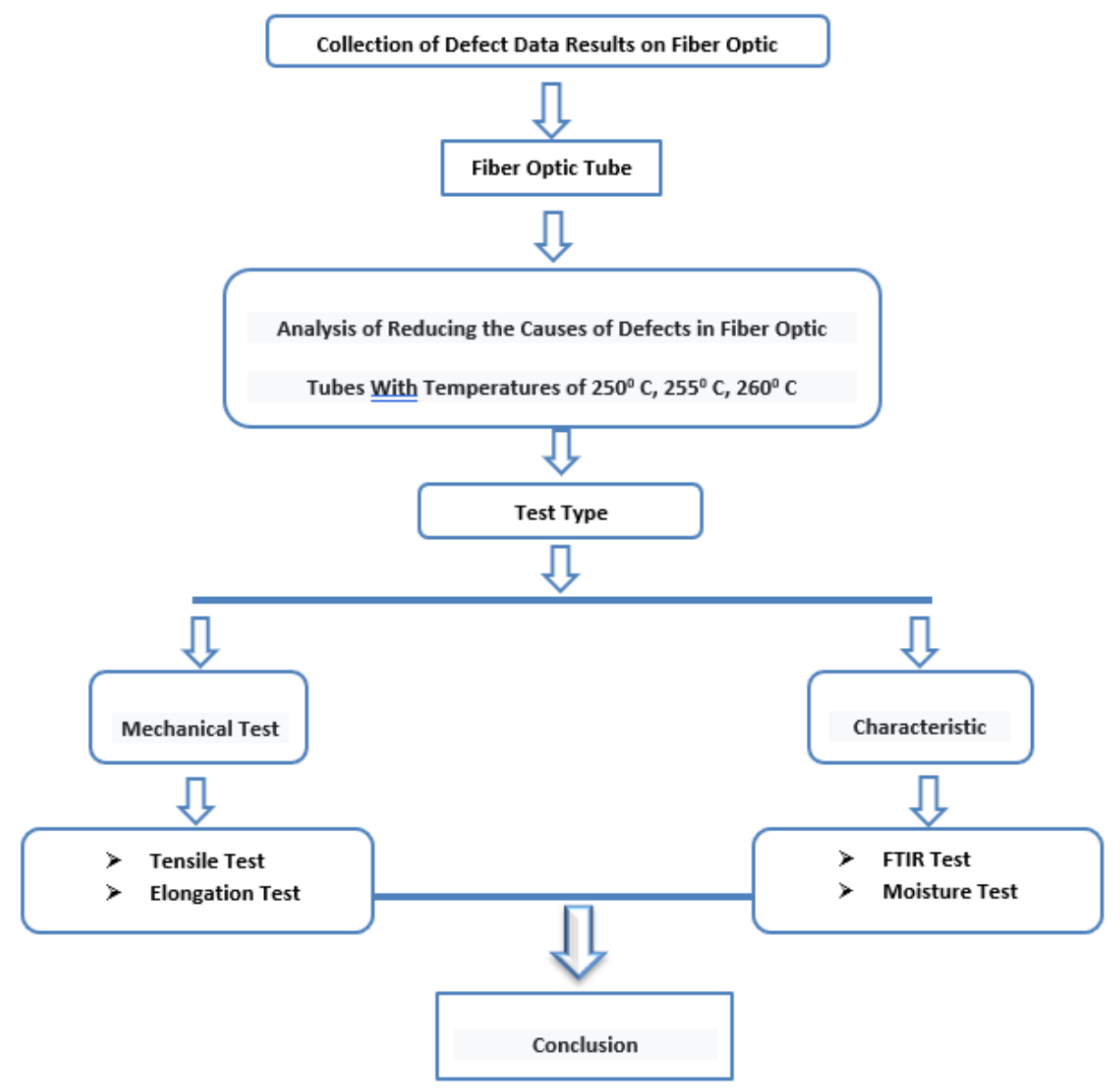

Figure 1. Flowchart of the research

\subsection{Materials}

Black master batch is widely used in the industrial world. Black master batch is a carbon black compound containing about $10 \%-50 \%$ carbon, resin and contains additives. Usually, it is used for coloring in the industrial world. 


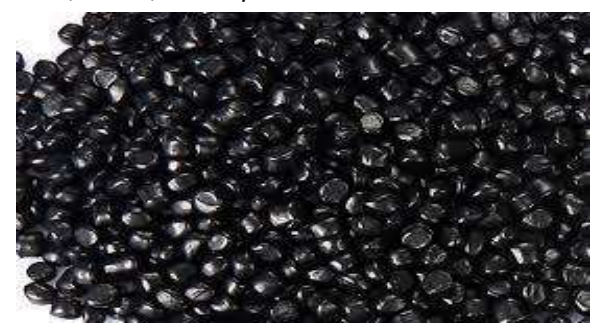

Figure 2. Master Batch Black

The melting point of the master batch is $130^{\circ} \mathrm{c}-170^{\circ} \mathrm{c}$, density $1.2-1.8 \mathrm{~g} \cdot \mathrm{m}^{-3,}$ humidity $\leq 0.15 \%$, grain diameter $1.8-3.8 \mathrm{~mm}[5]-[13]$.

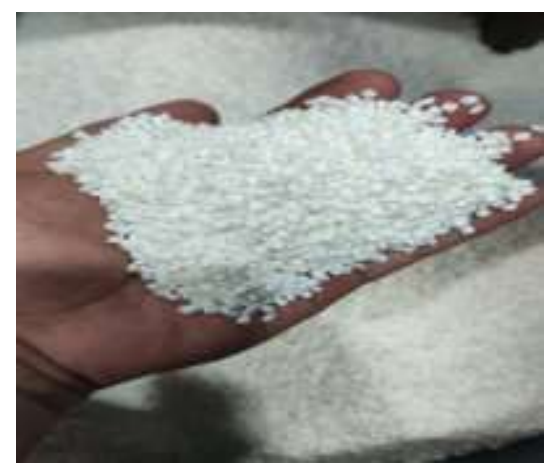

Figure 3. Polybutylene Terepthalate (PBT)

PBT (Polybutylene Terephthalate), is a thermoplastic engineering polymer of synthetic semicrystalline which is usually used as an insulator in the electrical industry. PBT density 1.30 g.cm ${ }^{-3}$, water absorption $0.3 \%$, melting point $225^{\circ} \mathrm{C}$, yield stress $60 \mathrm{MPa}$, Elasticity $50 \%$ [14][20].

\subsection{FTIR Methods}

FTIR (Fourier Transform Infrared Spectrometer), is a test carried out by obtaining an infrared spectrum from the absorption of liquids, solids or gases.

\subsection{Tensile Methods}

Tensile Test is a test to determine the characteristic properties of a material. By pulling a material, you will immediately know how the material reacts to the pulling force and know the extent to which the material increases in length. The experimental equipment for this tensile test must have a strong grip and high stiffness.

$\sigma=F / A$

\subsection{Elongation Method}

It is a test to determine the change in the maximum length of a specimen before it is cut off. And it is done by comparing the increase in length that occurs with the length of the material before: 
$\varepsilon=\frac{L_{1}-L_{O}}{L_{O} \times 100}$

\subsection{Moisture Methods}

Moisture test is a test to determine the moisture content of a sample or material, samples whose moisture can be measured in the form of liquid powder, or granular. The working principle of this humidity tool is to measure the mass of the material before and after being heated.

\section{Result and Discussion}

\subsection{Tensile Test}

The PBT tube has a diameter of $2.2 \mathrm{~mm}^{2}$, a thickness of $0.3 \mathrm{~mm}^{2}$ and a different temperature when made from $250^{\circ} \mathrm{C}, 255^{\circ} \mathrm{C}$ and $260^{\circ} \mathrm{C}$, cut into $15 \mathrm{~cm}$ long each sample for tensile testing.

- Temperature $250{ }^{\circ} \mathrm{C}$

$$
\begin{aligned}
\sigma & =\frac{\mathrm{F}}{\mathrm{A}} \\
\sigma & =\frac{81 \mathrm{~N}}{1.857 \mathrm{~mm}^{2}}=43.6 \mathrm{~N} / \mathrm{mm}^{2}
\end{aligned}
$$

- Temperature $255^{\circ} \mathrm{C}$

$$
\begin{aligned}
\sigma & =\frac{\mathrm{F}}{\mathrm{A}} \\
\sigma & =\frac{83 \mathrm{~N}}{1.857 \mathrm{~mm}^{2}}=44.6 \mathrm{~N} / \mathrm{mm}^{2}
\end{aligned}
$$

- Temperature $260^{\circ} \mathrm{C}$

$$
\begin{aligned}
\sigma & =\frac{\mathrm{F}}{\mathrm{A}} \\
\sigma & =\frac{85.5 \mathrm{~N}}{1.857 \mathrm{~mm}^{2}}=46 \mathrm{~N} / \mathrm{mm}^{2}
\end{aligned}
$$

\subsection{Elongation Test}

The PBT tube has a diameter of $2.2 \mathrm{~mm}^{2}$, a thickness of $0.3 \mathrm{~mm}^{2}$ and a different temperature when made from $250{ }^{\circ} \mathrm{C}, 255{ }^{\circ} \mathrm{C}$ and $260{ }^{\circ} \mathrm{C}$, cut into $15 \mathrm{~cm}$ long each sample for elongation testing.

- Temperature $250{ }^{\circ} \mathrm{C}$

$$
\begin{aligned}
\varepsilon & =\left(\frac{L_{I}-L_{O}}{L_{O}}\right) \times 100 \\
\varepsilon & =\left(\frac{73.17-20}{20}\right) \times 100 \\
& =265.85 \%
\end{aligned}
$$

\section{- Temperature $255^{\circ} \mathrm{C}$}

$$
\varepsilon=\left(\frac{L_{I}-L_{O}}{L_{O}}\right) \times 100
$$




$$
\begin{aligned}
\varepsilon & =\left(\frac{86.08-20}{20}\right) \times 100 \\
& =330.4 \%
\end{aligned}
$$

- Temperature $260^{\circ} \mathrm{C}$

$$
\begin{aligned}
\varepsilon & =\left(\frac{L_{I}-L_{O}}{L_{O}}\right) \times 100 \\
\varepsilon & =\left(\frac{87.07-20}{20}\right) \times 100 \\
& =335.35 \%
\end{aligned}
$$

\subsection{Humidity Test}

For Sample $250^{\circ} \mathrm{C}$

$$
\begin{aligned}
& \mathrm{a}=0.002 \text { (gram) } \\
& \mathrm{b}=4.734 \text { gram } \\
& \mathrm{c}=4.728 .5 \text { gram } \\
& \text { Water percentage }(\%)=\frac{(4.734-4.728)}{(4.734-0.002)} \times 100 \\
& =0.12679 \%
\end{aligned}
$$

From the results of testing the humidity of the PBT tube at a temperature of $250{ }^{\circ} \mathrm{C}$ the water content stored in the PBT tube is $0.12679 \%$.

$$
\begin{aligned}
& \text { For Sample } 255^{\circ} \mathrm{C} \\
& \begin{array}{c}
\mathrm{A}=0.002(\text { gram}) \\
\mathrm{b}=4.734 \text { gram } \\
\mathrm{c}=4.728,9 \text { gram }
\end{array}
\end{aligned}
$$$$
\text { Water percentage }(\%)=\frac{(4.734-4.727 .9)}{(4.734-0.002)} \times 100
$$$$
=0.12890 \%
$$

From the results of testing the humidity of the PBT tube at a temperature of $255{ }^{\circ} \mathrm{C}$ the water content stored in the PBT tube is $0.12890 \%$.

$$
\begin{aligned}
& \text { For Sample } 260^{\circ} \mathrm{C} \\
& \mathrm{a}=0.002(\text { gram }) \\
& \mathrm{b}=4.734 \text { gram } \\
& \mathrm{c}=4.727 \text { gram } \\
& \text { Water percentage }(\%)=\frac{(4.734-4.727)}{(4.734-0.002)} \times 100 \\
& =0.14792 \%
\end{aligned}
$$

From the results of testing the humidity of the PBT tube at a temperature of $260{ }^{\circ} \mathrm{C}$ the water content stored in the PBT tube is $0.14792 \%$. 


\section{$3.4 \quad$ FTIR Test}

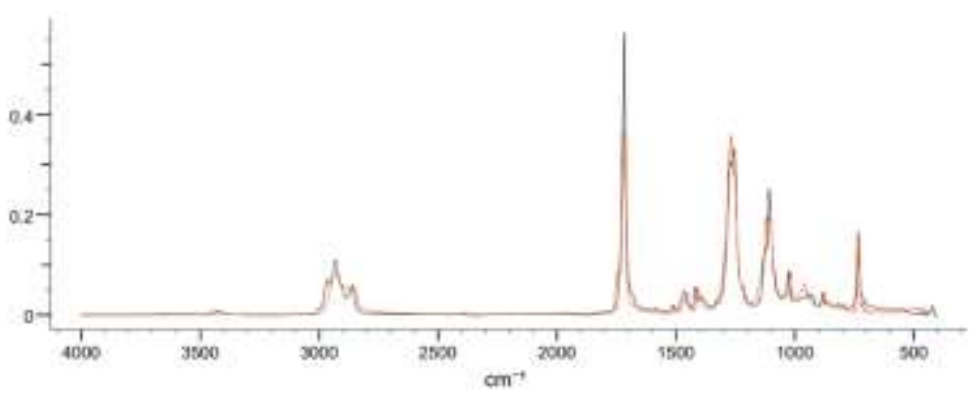

Figure 4. FTIR Test $250{ }^{\circ} \mathrm{C}$

In Figure 4, the results of the FTIR test with a wavelength of $4000-500 \mathrm{~cm}^{-1}$, the results of the $\mathrm{CH}$ bonding of the PBT Tube at the highest wave peak are $2923.54 \mathrm{~cm}^{-1}, 1725.10 \mathrm{~cm}^{-1}$, there are also $\mathrm{CH}$ aldehydes bonds at the length wave $2852.19 \mathrm{~cm}^{-1}, 935.30 \mathrm{~cm}^{-1}, 916.02 \mathrm{~cm}^{-1}, 873.59 \mathrm{~cm}^{-}$ ${ }^{1}, 811.88 \mathrm{~cm}^{-1}$, carbonyl bond $\mathrm{C}=\mathrm{C}$ at wavelength $1708.61 \mathrm{~cm}^{-1}$, and the last is aromatic bond at wavelength $1504.20 \mathrm{~cm}^{-1}, 408.83 \mathrm{~cm}^{-1}, 532.25 \mathrm{~cm}^{-1}, 474.40 \mathrm{~cm}^{-1}, 455.12 \mathrm{~cm}^{-1}, 437.76 \mathrm{~cm}^{-1}$, $408.83 \mathrm{~cm}^{-1}$.

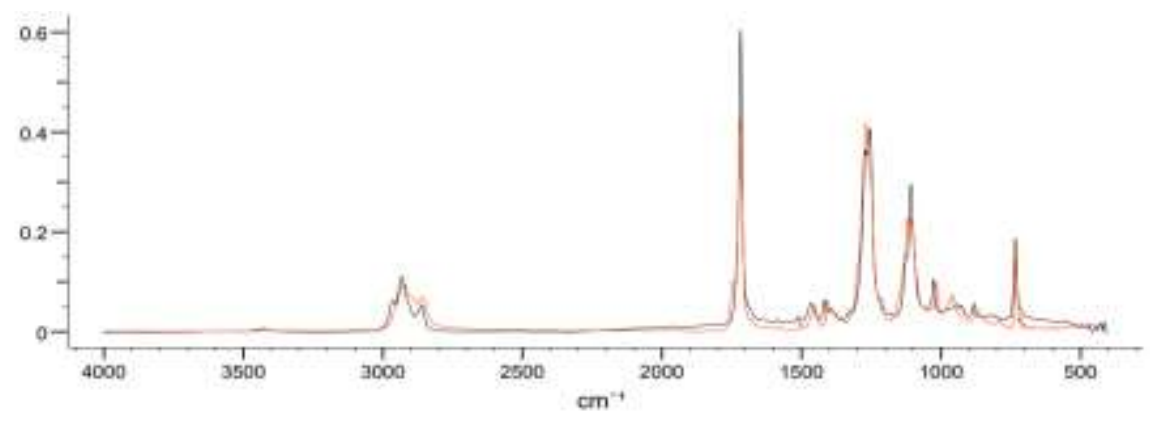

Figure 5. FTIR Test $255{ }^{\circ} \mathrm{C}$

In Figure 5, the results of the of FTIR test results with a wavelength of $4000-500 \mathrm{~cm}^{-1}$, the results of $\mathrm{CH}$ bonds from tube PBT at the highest wave peak are $2921.61 \mathrm{~cm}^{-1}, 1725.10 \mathrm{~cm}^{-1}$, there are also $\mathrm{CH}$ aldehydes bonds at wavelengths $935.30 \mathrm{~cm}^{-1}, 916.02 \mathrm{~cm}^{-1}, 873.59 \mathrm{~cm}^{-1}$, $811.88 \mathrm{~cm}^{-1}$, carbonyl bond $\mathrm{C}=\mathrm{C}$ at wavelength $1708.61 \mathrm{~cm}^{-1}$, and the last is aromatic bond at wavelength $1504.20 \mathrm{~cm}^{-1}, 553.47 \mathrm{~cm}^{-1}, 485.97 \mathrm{~cm}^{-1}, 458.97 \mathrm{~cm}^{-1}, 437.76 \mathrm{~cm}^{-1}, 420.40 \mathrm{~cm}^{-1}$, $406.90 \mathrm{~cm}^{-1}$.

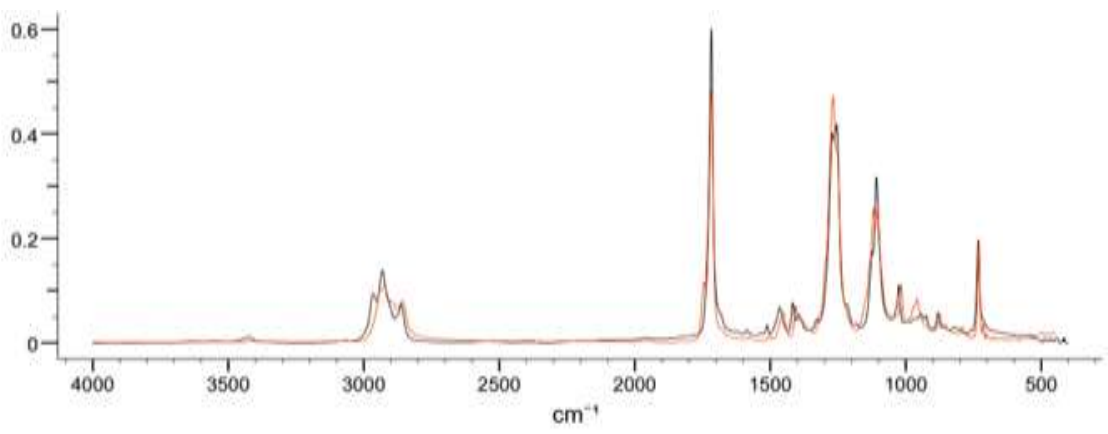


Figure 6. FTIR Test $260{ }^{\circ} \mathrm{C}$

In Figure 6 the results of th FTIR test results with a wavelength of $4000-500 \mathrm{~cm}^{-1}$, the results of $\mathrm{CH}$ bonds from tube PBT at the highest wave peak are $2921.61 \mathrm{~cm}^{-1} 1,725.10 \mathrm{~cm}^{-1}$, there are also $\mathrm{CH}$ aldehydes bonds at wavelengths $935.30 \mathrm{~cm}^{-1}, 916.02 \mathrm{~cm}^{-1}, 873.59 \mathrm{~cm}^{-1}, 811.88 \mathrm{~cm}^{-1}$, carbonyl bond $\mathrm{C}=\mathrm{C}$ at wavelength $1708.61 \mathrm{~cm}^{-1}$, and the last is aromatic bond at wavelength $1504.20 \mathrm{~cm}^{-1}, 553.47 \mathrm{~cm}^{-1}, 485.97 \mathrm{~cm}^{-1}, 458.97 \mathrm{~cm}^{-1}, 437.76 \mathrm{~cm}^{-1}, 420.40 \mathrm{~cm}^{-1}, 406.90 \mathrm{~cm}^{-1}$.

\section{Conclusion}

The results of the tensile test on the PBT tube with temperatures of $250{ }^{\circ} \mathrm{C}, 255^{\circ} \mathrm{C}$ and $260{ }^{\circ} \mathrm{C}$ can be concluded that the value of the tensile test results which has the largest value is obtained at a temperature of $260{ }^{\circ} \mathrm{C}$, which is $46 \mathrm{~N} \cdot \mathrm{mm}^{-2}$. The results of the elongation test on the PBT tube with temperatures of $250{ }^{\circ} \mathrm{C}, 255{ }^{\circ} \mathrm{C}$ and $260{ }^{\circ} \mathrm{C}$ can be concluded that the value of the elongation test results which has the largest value is obtained at $260{ }^{\circ} \mathrm{C}$, which is $335.35 \%$. The results of the humidity test on the PBT tube with temperatures of $250{ }^{\circ} \mathrm{C}, 255^{\circ} \mathrm{C}$ and $260{ }^{\circ} \mathrm{C}$ can be concluded that the value of the humidity test results has the smallest water content value, which is obtained at a temperature of $260{ }^{\circ} \mathrm{C}$ at $0.14792 \%$. In the results of the PBT tube FTIR test, the types of bonds and compound groups have similarities to all of these samples. From all the tests carried out, it was concluded that the effect of temperature on the manufacture of PBT tubes was very influential on the quality of the product to be made.

\section{REFERENCES}

[1] PJ Winzer and DT Neilson, AR Chraplyvy - Optics express, 2018.

[2] F. Nur, Penanganan Gangguan Pada Perangkat Metro-Ethernet Di PT. Telekomunikasi Indonesia Tbk. Area Network Solo, Jawa Tengah, Yogyakarta: Universitas Gadjah Mada, 2014.

[3] W. Utomo and Yunianto, Analisa Penyambungan Kabel Fiber Optic Menggunakan Fusion Splicer Dan Adapter Fiber Optic, 2018.

[4] I. Hanif, and D. Arnaldy, Analisis Penyambungan Kabel Fiber Optik Akses dengan Kabel Fiber Optik Backbone pada Indosat Area Jabodetabek.Multinetics, 2017.

[5] M. D. Sebayang, "The microstructure of the radiation effect of the heat on the complete cable NYM," Inovation in Polymer Science and Technology, 2016.

[6] M. D. Sebayang, S. Gideon, and J. L. Panjaitan, Pengaruh Perlakuan Panas Terhadap Kabel PVC, Majalah Polimer Indonesia, vol. 18, no. 1, 2015.

[7] M. D. Sebayang, S. Gideon, dan M. Sianturi, Pengaruh Efek Radiasi Panas Kabel Nym Khususnya Selubung Dan Isolasi Pada Gedung Kantor Yang Terbakar, 2013.

[8] M. D. Sebayang, and B. M. Tarigan, "Pengoperasian dan Perawatan Generator Set 500 KVA," Seminar Nasional Inovasi dan Rekayasa Teknologi, 2013.

[9] M. Abdul, Sharing Knowledge Fiber Optic In Indosat, Jakarta, 2017.

[10] F. N. Hanifah., Pengaruh Suhu Terhadap Perubahan Pola Interferensi Pada Fiber Optik, 2018. 
[11] H. Irfan, and A. Defiana., "Analisis Penyambungan Kabel Fiber Optik Akses dengan Kabel Fiber Optik Backbone pada Indosat Area Jabodetabek," Jurnal Multinetics Vol.3 No.2, 2017.

[12] M. Abdul, Sharing Knowledge Fiber Optic In Indosat, Jakarta, 2017.

[13] M. Antaresa and A. Ajub, Fiber Optik Pada Jaringan Backbone Topologi Star Di Pt Dirgantara Indonesia Dalam Arsitektur Fttb (Fiber To The Building), Semarang, 2013.

[14] R. S. Stein and A. Misra, "Morphological studies on polybutylene terephthalate," Journal of Polymer Science: Polymer Physics Edition, vol. 18, No. 2, 1980.

[15] M. Hoppe, P. de Voogt., and R. Franz, "Oligomers in polyethylene naphthalate and polybutylene terephthalate-Identification and exploring migration," Food Packaging and Shelf Life, vol. 17, 2018.

[16] M. A. A. Saidi, F. S. Mazlan, A. Hassan, R. A. Rashid, and A. R. Rahmat., "Flammability, Thermal and Mechanical Properties of Polybutylene Terephthalate/Dolomite Composites," Journal of Physical Science, Vol. 30 (3), 175-189, 2019.

[17] N. A. Dwi, Pengenalan Sistem Komunikasi Serat Optik. Telkom University, 2017.

[18] Y. M. Indra and D. Ryana, M. Rosmiati, Perancangan Jaringan Fiber To The Home (FTTH), Universitas Telkom, 2017.

[19] Alief Ridwan, Teknik Penyambungan Serat Optik Dengan Metode Penyambungan Fusi (Fusion Splicing), Universitas Diponegoro, 2012.

[20] W. D. Setyo, R. D. Oktaviasari, R. D. Oktaviasari, "Teknik Penyambungan Serat Optik Dengan Metode Penyambungan Fusi, 2015. 